Вплив амфіфрільних сполук на постгіпертонічний лізис еритроцитів

О.О. Чабаненко, Н.А. Єршова, Н.М. Шпакова

Інститут проблем кріобіології і кріомедицини НАН України, м. Харків, Україна

Effect of Amphiphilic Compounds on Posthypertonic Lysis of Erythrocytes

O.O. Chabanenko, N.A. Yershova, N.M. Shpakova Institute for Problems of Cryobiology and Cryomedicine of the National Academy of Sciences of Ukraine, Kharkiv, Ukraine

To study the damage factors, acting at the thawing stage of erythrocytes, cryopreserved under protection of penetrating cryoprotective agent, as well as transfer into recipient's bloodstream, posthypertonic shock (PHS) is used. Recently there was demonstrated the ability of chlorpromazine to reduce posthypertonic lysis (PHL) level of human erythrocytes [Semionova et al., 2017].

Research aim was to study the effect of anionic sodium decyl sulfate (C10), cationic trifluoperazine (TFP) and nonionic decyl- $\beta$,D-glucopyranoside (DGP) on posthypertonic lysis of human erythrocytes at 37 and $0^{\circ} \mathrm{C}$.

Posthypertonic shock was simulated by transferring erythrocytes from dehydration medium $(1.65 \mathrm{~mol} / \mathrm{L} \mathrm{NaCl})$ to rehydration one $(0.15 \mathrm{~mol} / \mathrm{L} \mathrm{NaCl})$ at 37 and $0^{\circ} \mathrm{C}$. Amphiphilic compounds were added into rehydration medium prior to transfer of the cells. After the combined action of amphiphilic compounds and PHS, the cell suspension was kept for $30 \mathrm{~min}$ at certain temperature range of $0-37^{\circ} \mathrm{C}$. The hemolysis level of erythrocytes was measured spectrophotometrically $(\lambda=$ $543 \mathrm{~nm}$ ). The morphological features of the cells were evaluated by light microscopy using microscope Axio Observer Z1 with a thermal attachment.

It was established that all amphiphilic compounds, regardless of their physicochemical properties, reduced the PHL level of erythrocytes at $0^{\circ} \mathrm{C}$ (unlike at $37^{\circ} \mathrm{C}$ ) and showed sufficiently high antihemolytic activity $(60-70 \%)$. Thus, TFP and $\mathrm{C} 10$ were effective within the concentration range of $100-200$ and $200-600 \mu \mathrm{mol} / \mathrm{L}$, respectively, while the antihemolytic activity of DGP manifested in a wider concentration range of $400-1600 \mu \mathrm{mol} / \mathrm{L}$.

It was shown that when heating the cells survived after PHS effect at amphiphiles presence $\left(0^{\circ} \mathrm{C}\right)$, the development of hemolysis was observed when using TFP and DGP, but not anionic C10. Comparative analysis of morphology of these cells showed that the increase temperature using TFP $(150 \mu \mathrm{mol} / \mathrm{L})$ led to the transformation of erythrocytes into spherocytes with a further rise of ghosts number, while $\mathrm{C} 10(400 \mu \mathrm{mol} / \mathrm{L})$ caused a slight increase in cell volume without amount changing.

Thus, the high efficiency of anionic $\mathrm{C} 10$, cationic TFP and non-ionic DGP under PHS conditions of human erythrocytes at $0^{\circ} \mathrm{C}$ was shown, however, the cells survived after the combined action of PHS and amphiphiles $\left(0^{\circ} \mathrm{C}\right)$ were resistant to subsequent heating only when using anionic $\mathrm{C} 10$. Apparently, this compound inhibits a reorganization of erythrocyte membrane, occurring at higher temperatures, and as a result, prevents the development of hemolytic transmembrane pore. https://doi.org/10.15407/cryo30.03a.286

Морфологічна характеристика ендотелію аорти щурів із хронічною нирковою недостатністю після введення кріоекстракту плаценти щура, застосування медикаментозної блокади РААС та їх поєднаної дії

Ю.О. Чиж, М.В. Рєпін, Л.М. Марченко, В.І. Строна, Т.П. Говоруха

Інститут проблем кріобіології і кріомедицини НАН України, м. Харків, Україна

\section{Morphological Characteristics of Aortal Endothelium in Rats with Chronic Renal Insufficiency Following Injection of Rat Placental Cryoextract, Application of RAAS Medicated Blockade and Their Combined Action Yu.O. Chizh, M.V. Repin, L.M. Marchenko, V.I. Strona, T.P. Govorukha \\ Institute for Problems of Cryobiology and Cryomedicine} of the National Academy of Sciences of Ukraine, Kharkiv, Ukraine

Pathogenesis of chronic renal failure (CRF) involves endothelial dysfunction, morphological characteristics of which correlate with progressive reduction in renal functions.

The aim of the research was to investigate the effect of the rat placental cryoextract (RPC), a RAAS medicated blockade and their combined action on the morphological state of the aortal endothelium in rats with experimental CRF.

CRF was modeled by a single injection of $50 \%$ aqueous glycerol $(10 \mathrm{ml} / \mathrm{kg})$. All the animals were sacrificed in 16 weeks. The norm group made 6 animals. Control group comprised the animals with CRF (1). The rats with CRF were divided into groups $(n=6)$. The course of treatment on the second week of the disease involved: injections of RPC (2); a RAAS medicated blockade (3); combined application of RPC and a RAAS medicated blockade (4). Two courses of treatment (on the $2^{\text {nd }}$ and $9^{\text {th }}$ weeks) involved: injection of RPC (5); a RAAS blockade (6); combined application of RPC and a RAAS blockade (7). To prepare the RPC placental tissue was washed with saline, homogenized, frozen to $-20^{\circ} \mathrm{C}$ and stored for 24 hours. After thawing, the homogenate was mixed with saline (1:1), centrifuged at $4000 \mathrm{rpm}$. The supernatant was stored in liquid nitrogen. RPC was intramuscularly injected by $0.5 \mathrm{ml}$ thrice a week. A RAAS medicated blockade was done with enalapril and spironolactone, which were injected daily for 2 weeks per os at a dose of $0.5 \mathrm{ml}$ suspension. Thoracic aorta endothelium was evaluated with a microscope using silver-impregnated drugs. The adjacency and surface area of the endothelial cells were calculated per 100 cells using the Biovision 4.0 morphometric program.

Simulating of CRF in the animals of all groups resulted in the interruption of the endothelial cell orderliness and an increase in the number of microendotheliocytes (Me). Following RPC injections (groups 2 and 5) the number of cells with the surface area of $200-500 \mu \mathrm{m}^{2}$ comprised 81 and $95 \%$, while the amounts of Me were lower (29 and 48\%, respectively). In group 1, the amount of Me (area up to $300 \mu^{2}$ ) increased to $69 \%(7 \%$ in the norm), and $23 \%$ of cells showed adherence to $3-4(13 \%$ in the norm), indicating high proliferative activity. Group 2 had high proliferative activity (contacts $3-4)-20 \%$. Two-course combined treatment increased both proliferative potential ( $26 \%$ of cells with adjacency of 7-8) and endothelium proliferative activity ( $17 \%$ of cells with adjacency of 3-4).

Combined application of a RAAS medicated blockade with injection of RPC stimulated the proliferation and reparation in the aortal endothelial lining, which was manifested by recovery of the cell ratios of adjacency and surface area. 